\title{
A Prescriptive Approach To Introducing An Experiential Entrepreneurship Course In Undergraduate Education
}

Peter S. Sherman, (Email: ps45@ebansville.edu), University of Evansville

\begin{abstract}
Universities are continually adding entrepreneurship courses to their curriculum. Duhaime and Hitt (2000) found 82\% of schools offered entrepreneurship courses at the undergraduate level and $69 \%$ of masters programs had offerings in entrepreneurship. A much smaller number of programs offer courses that require that the students actually start the business. The requirement of new venture creation adds an enormous amount of complexity to the teaching experience. Although each pedagogical endeavor will vary, this manuscript details one such experience, including the challenges and various successes of the course and offers recommendations for those professors and/or deans interested in adding a real-life experiential entrepreneurship course to their curriculum.
\end{abstract}

\section{INTRODUCTION}

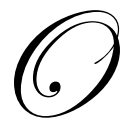

nce on a family vacation, we had the opportunity to visit a natural underground cave. It was explained to my young children that we would be riding in a jeep and going deep into the cave. Upon hearing this, my four year old son looked up with trepidation in his eyes and said "But Dad, there are bears in caves." He was right, there are bears in caves, but not in the caves we were visiting.

I have seen that same look in the eyes of students when they are told that one of the requirements of the entrepreneurship course is that they actually have to start the business. The look conveys the message "but professor, there are risks in entrepreneurship.” And while there are risks in business, the classroom environment provides an excellent opportunity to start a business with the protection and guidance that comes from the University setting. This manuscript describes the experience of running the pilot course in entrepreneurship where all of the students in the class were required to create a new company. I am hopeful that this manuscript will help others in their attempts to create such a course and offer some recommendations for those who are considering such an endeavor.

The experiment into entrepreneurship began with a conversation with the Dean of the School of Business Administration concerning the creation of an experiential course in entrepreneurship that went beyond the usual creation of a business plan and analysis of case studies. A course where the students actually start the business, do their own market research, keep their own books, actually create a new venture. After some careful consideration about what it would take to create such a course, the answer, as it almost always is, was that we needed money. Money is necessary for attorneys, accountants and accounting software and funds to actually start the businesses. So the announcement that the School of Business Administration had received a $\$ 500,000$ grant to help launch this program should have indicated our problems were solved. But, as any entrepreneur could tell you, that is not the case. It takes more than just money and a good idea to make something work. The following is the first hand account of the process of creating an experiential entrepreneurship course with feedback from the students and advice for others. 


\section{DESCRIPTION OF COURSES}

The entrepreneurship class was a two semester course where the first semester includes educating the students about entrepreneurship and having them create a business plan. However, at the end of the semester, the students were required to present their plans to a board of investors who provided feedback and evaluated the worthiness of the business plans. A grant to the University made available $\$ 500,000$ for the start-up of new businesses. At the end of the first semester, the board of investors made determinations as to whether or not the businesses should be funded. The second semester course taught the students how to run the new businesses that they were required to create.

The goal of the course was to create a set of businesses that would provide a source of reoccurring revenue for the students. In other words, the goal was to avoid the one time source of revenue model, such as a bake sale. This course was designed to establish businesses that would be ongoing and would produce the opportunity to teach students about marketing, accounting, income statements and other financials. This course is unique in two respects: very few universities mandate new business start-up as a course requirement and even fewer have this type of course as a requirement for all business students.

By semesters end, there were nine businesses started. The businesses ranged in success with some showing short-term losses while others were quite profitable. Of the nine businesses started, four appear to be ongoing viable businesses.

\section{PREPARATION FOR THE COURSE}

Prior to the introduction of the course, I felt well prepared to lead the course. My entrepreneurial background included an area of concentration in my Ph.D. program; previous experience teaching in entrepreneurship and in my prior career, I had started an investment business. Consequently, I was familiar with the process of starting a business, incorporating the business and had even been though SEC audits. All of this training did not prepare me for the challenges that lie ahead in such a unique course. This course was unique in that students were required rather than encouraged to start the businesses. In less than a year the course went from concept to reality.

In order to insure that the pilot course could be run, we first needed to ensure that enough students enrolled. As a small private university, the students are required to meet with their advisors (professors) prior to enrolling in courses. To meet the enrollment goals, advisors were asked to market the course so that sufficient numbers of students would enroll. By the time the course started, there were 15 students enrolled, 14 male and one female. The female student dropped the course when she realized it was not a required course. To date, there is no clear explanation for the gender makeup of the course. In an attempt to understand the gender selection the students were surveyed to understand why they did or did not take the course. Most who were not in the course indicated that they either did not need the course or had not heard about the new offering. It was not clear whether female students "selfselected" out or if male students were marketed to more aggressively. In the fall, the course, with its 14 students was launched. After implementing the course, there were numerous issues that needed to be considered for anyone wanting to replicate such a course.

\section{CONSIDERATION FOR INSTRUCTORS}

\section{Assignment Of Profits And Losses}

A primary concern of the class was the question of who should get to keep the profits and be responsible for the losses. In other words, how experiential did we really want the course to be? After some considerable thought, it was decided that the money, positive or negative, would be attributed to the startup companies. The students were creating the business, performing all the necessary work and should be entitled to the value created. The students would be expected to payback any loans and share profits if the company was funded with equity. This for-profit model contrasts with what is done at schools such as Babson College, which requires the students donate the profits to a charity, we felt removed the incentive structure for students. Ultimately, it was decided that the students were taking 
the risks and should be entitled to any rewards. A second issue that needs to be resolved is the appropriate scholastic level of the students.

\section{Appropriate Scholastic Level}

The pilot version of the course was created for sophomores. Teaching Entrepreneurship at the sophomore level created some challenges in the first semester; particularly when the students were asked to create pro forma financials. Although the students were taking their first accounting course concurrently, for many, this was their first introduction to an income statement and balance sheet. Consequently, many struggled trying to create the pro forma statements for their businesses. Although it was an excellent learning experience for the students, it also created anxiety and frustration. Ultimately, we believe the outcomes will be beneficial for the students insomuch that they will enter their junior year with the real world experience of starting a business and therefore concepts such as balance sheets and financial ratios will likely be more understandable. An additional element for instructors is the possibility that students will not perceive the class positively.

\section{Student Evaluations And Perceptions}

An experiential course in entrepreneurship has its share of highs and lows. If run properly with the right structure and motivated students, the course can be outstanding. However, any course that requires the startup of a business is going to have its share of ambiguity. The risk to instructors teaching this course is that evaluations may suffer because many of the course outcomes are related to uncertain events that are outside of the control of the student or professor. It is in the instructors best interest to remove as much of the uncertainty and ambiguity as possible without stifling the students' creativity. This can be accomplished by attempting to set and keep strict deadlines, even deadlines for the dates when first sales must be achieved, which may prove difficult.

Another consideration for those teaching this type of course is that instructors may be negatively impacted if their university uses adjusted scores. To illustrate, if the university uses the Individual Development \& Educational Assessment (IDEA) evaluation system; student satisfaction scores are adjusted based on factors such as the students desire to take the course. In the pilot version of the course, every student that filled out the evaluation form in the entrepreneurship course indicated they had a strong desire to take the course which negatively impacted the adjusted evaluations. Another challenge of the course was dealing with tax issues.

\section{Tax Considerations}

One of the more complex situations deals with the issue of taxes. Unfortunately there is not a clear and simple solution for handling this situation. Business students can take an entire semester long course on corporate taxation, which would not necessarily cover everything they need to know about corporate taxation. In this course, accounting faculty were utilized for consultation, but the students were advised that as their businesses become more successful and/or complex, they should seek professional tax advice. There was also the issue of whether or not to let the students work individually or in groups.

\section{Group Projects}

In the pilot version of the course, the students had the choice to work as individuals or in groups. The rationale for this policy is that the class arose from the fact that the course involved real money. Consequently, it seemed unfair to artificially restrict an individual's right to start the business on their own and split profits, just to teach the value of teamwork. The tradeoff for the instructor is that the workload increases substantially if students are allowed to work individually. The result of giving students the choice of being in groups was that five students worked individually and the remaining eight students worked in groups. The students were asked if they should be required to work in groups and the responses were split. Seven of the eleven said that group work should not be required. Although many of the students who said that group work should not be required, stated that it should be highly encouraged for a variety of reasons, primarily related to the fairness of workloads. It is highly recommended 
that if group work is required, partnership agreements should be utilized so there is no confusion about who owns the businesses. Additional considerations involve non-typical students in the class.

\section{International Students And The Ncaa}

Instructors need to know how to stay within the guidelines stipulated for NCAA student athletes and international students. Student athletes have numerous restrictions dealing with employment and their ability to earn money. A general rule, although one must always check with their compliance department, is that starting a business is permissible for student athletes if business start-up is a requirement of the course. This rule is broad and there are numerous additional restrictions, i.e. they are prohibited from selling and making a profit from the team they participate on. Therefore it is important to work with the university's compliance department. International students also present complications because of the fear that something would be a violation of the individual's "student visas" status. International students must be very careful to make sure the business is categorized as course work. A further challenge in the course is the challenge of inviting appropriate guest speakers.

\section{Guest Speakers}

The use of guest speakers in entrepreneurship is a very popular approach in the classroom. Winslow, Solomon and Tarabishy (1997) surveyed the entrepreneurial landscape and found that of the 207 respondents, 108 asked business owners into the classroom and 132 used other guest speakers in their courses. Students seem to enjoy the expertise and real life experience these speakers provide. However, there is a risk that speakers can scare the students into inaction. Although some guest speakers provided powerful positive messages, at times, some business owners would pontificate about how they were able to pull themselves out of dire straits and the difficulties of the entrepreneurial process. These sermons (speeches) can have the effect of frightening students about their own ventures.

Attorneys are also a valuable resource in the classroom because there cannot be an expectation that an entrepreneurship professor knows enough about corporate law to be able to answer what inevitably becomes complex questions about specific situations. Also, students may be intimidated about filling out legal forms and justifiably so. If a problem were to arise in their business, there would likely be an attempt to pierce the corporate shield provided by articles of incorporation. An attorney can help ease these tensions. The downside is that an attorney can also convince students that they will be sued in their new venture, which is a possibility but a generally remote one for the size and scope of the businesses created in the university setting. There seems to be a fine line between providing a realistic preview of entrepreneurship and putting too much fear into the students. There were a multitude of issues that arose from having real money in the classroom.

\section{Money In The Classroom}

The availability of funds created both opportunity and anxiety for the students. The students, like all entrepreneurs, wanted to keep all of the profits, while having none of their capital at risk. Even though funding was available, not one of the student corporations took advantage of the money that was available from the University's grant. Part of the problem arose from the dichotomous role of the University playing both advisor and lender. As the advisor, the instructor taught the students that they should try to keep as much of the company's equity as possible and to take as little risk as possible, but there was also a fiduciary responsibility to the University's grant to recoup some funds to ensure that the program is viable into the future. This duel role mentality also played into the issuance of debt.

The money was easily available at a nominal rate particularly considering that these were non-secure loans. There was a disconnect between the theory taught in class and the practicality of the course. In the first semester, the students were taught about the dangers of debt and the impact of debt on financial statements and profitability. In the second semester, they were told that loans were available to them. Unfortunately, there was no practical way to explain to the students that although there was an expectation of repayment, the money was for the purposes of learning and loans would likely be forgiven. There was a fear that this insinuation would create a moral hazard 
whereby the students would engage in overly risky businesses because there was no personal accountability. As mentioned, not one of the student businesses chose to use the money that was made available, rather they found other ways to finance the business. The students were surveyed as to why they did not take advantage of financing and the responses varied, but tended to involve a fear of debt and/or having to answer to someone. One student indicated that he was "afraid of borrowing even if I did not have to pay it back." Another indicated that he "didn't want debt or to have to answer to the School of Business Administration. I wanted to own and run the company the way I wanted to." Another responded similarly by saying, "I did not want them (the University) to be involved." In short, they wanted the companies to be run independently and without debt. The issue of accountability arose in other areas.

There was a question of how exactly did one determine if the amount of sales and expenses recorded were accurate. In the pilot program, there was consideration for having the students turn in their bank statements, but in the end, concerns over privacy won out. However, going forward there would certainly be some consideration for this requirement since part of the grade is based on company performance. The above issues are items that are important for anyone considering an experiential course in entrepreneurship; the following are some of the specific challenges that arose in the course.

\section{CHALLENGES}

\section{Controlling Expectations And Perceptions}

Once word about the entrepreneurship course canvassed the campus, the rumors and misperceptions about the course also spread. The news that $\$ 500,000$ was available for business startups quickly spread around campus. By the time the course was starting, there was a common belief that each of the students would be given $\$ 5,000$ riskfree to start the business. This rumor became so prevalent that students from other disciplines and even other professors were inquiring about how they, too, could get in on this class. When the students found out the reality, which was that they could either take a loan from the fund or give up a stake in their business, there was considerable disappointment. One student surveyed about why his company had not taken advantage of the money from the University, replied that: “...the money was promised at first and somehow it turned into a loan.” These comments were generated despite the fact that it was explicitly stated in the syllabi that money would be available as either a loan or equity.

Another area that needed to be controlled was the expectations regarding the scale of the businesses. Two of the students had come up with an innovative idea that would have required significant electrical engineering experience, large scale production facilities and an enormous capital infusion for patent protection. The students had to be reminded that they were taking a two semester course and there was an expectation that they be selling their product sometime in the second semester. They eventually settled on a gift basket business. There were also some unforeseen expenditures for the University.

One of the more contentious issues in the creation of the course was trying to understand what liability the University had for offering such a course. Initially, various universities were contacted to see how they dealt with this issue and it was found that some others were essentially hoping nothing bad would happen, but not purchasing additional insurance. Most universities do have insurance policies that protect them in the event of a lawsuit, but there was/is a question of whether or not they covered student businesses. In the final analysis, there will likely be an expensive rider attached to the University's insurance policy. Another challenge that arose was trying to get students to adhere to deadlines when the projects involved activities outside of the classroom.

\section{Student Deadlines}

One of the more difficult situations was trying to set and keep deadlines for the students. In the classroom, the professor can state that an assignment is due by a certain date and expect to get that assignment. It is much more difficult to say that students must have a product produced and/or sold by a certain date. In reality many deadlines must be moved or abandoned. The changing deadlines caused more stress toward the end of the semester at a time 
when the students had tests and term papers due. Another challenge in the creation of the course was trying to assess the proper workload for the course.

\section{Appropriate Workload}

In a course where a business is created, much of the work is done outside the class and progress difficult to measure. Most students thought that the workload was appropriate, but many of the students struggled with the boom/bust nature of the work. There would be weeks where there was no "assigned" work, but there was an expectation that work was being conducted on the business. That, of course, was not always the case. Others found the idea of running a business consuming, one student noted that the workload "wasn't bad, but there was not a single day when I didn't think about the business.” Several students questioned whether it is reasonable to expect a student to open a business while taking a full course load. In addition to the workload considerations, questions about how to grade students appropriately also arose.

\section{Grades}

The issue of grading raised particular concern when the course was being introduced to the universities curriculum committee. Specifically, does a failing business constitute a failure in the course or what should be done if the business is never launched? In part to ease the minds of the curriculum committee and the students, the course was designed with a significant number of projects, including the creation of a business plan and an annual report, so the entire grade was not based on business performance and the class also contained academic rigor. The course was designed with multiple criterions for grading in addition to the course performance. This allowed for some margin of error in the event factors outside of the control of the student (i.e. a vendor backing out at the last moment) could be overcome by other coursework. In addition to earning a solid grade, the students found out that they would have numerous obstacles in class, specifically with the creation of their businesses.

\section{Challenges Of New Venture Creation}

In total, there were nine businesses created. One of the groups decided that they wanted to sell T-shirts on campus. The University is small enough that it had not attracted many competitors in this area. Their first sale was to create t-shirts for an event in the business school. The students had no money to order the shirts and did not want to take even a short term loan, so it was agreed that the business school would prepay the order. When the students requested payment from the accounting department, they were first asked to submit their articles of incorporation (which they did) and the invoices showing the cost of the t-shirts and printing. The Accounting Department informed the students that they would pay only the original costs thereby taking away any mark up for the student business. It took a long meeting with the accounting department to convince them that this was a legitimate for-profit business. The t-shirt company eventually received payment and the company actually received a positive mention write-up in the student newspaper. When the manager of the campus bookstore saw the article (and became concerned about the competition), he called to make sure that the student business had followed the proper procedures for using the University's name, which fortunately the students had done. With all of these challenges, there were also great successes.

\section{Successful Moments}

There were, no doubt, challenges in the creation of this course, but there were also successes. The following is a description of some of the highlights, successes and best practices that arose from the course.

\section{Student Creativity}

One of the more impressive aspects to the course was the student's creativity. Early on in the first semester, the class held a brainstorming session. It was an early concern that there would not be enough ideas generated to get businesses started. The student creativity was amazing and in this first session, there were over fifty ideas generated. Many of the ideas were easily discarded, but at least a dozen were potentially viable businesses. 


\section{Competitor Reviews}

One of the more effective projects the students engaged in was a competitor review. This project was assigned in the second semester and the students were asked to research a competitor and find out what makes them successful or not successful. They were asked to analyze the company's strategies and decide what they would emulate or avoid. This project helped open the eyes of many of the students about how they could position their current businesses in the market. One company that was interested in selling care packages to students realized they could segment the market and increase sales by diversifying away from a one product line. There were also individual success stories.

\section{The Underground Arcade}

The business who likely overcame the most obstacles was the Underground Arcade. The company had planned on placing arcade games in the student center. In the early part of the semester, the student conducted market research to see if there truly was a demand and he found that the demand was high. Inspired by this feedback, the student began discussions with the University Administration, who told him in no uncertain terms that the business could not be located in the Student Center. They felt it would be disruptive to the learning environment. Consequently, the student tried several other locations on campus and eventually found a student dorm that was agreeable to the concept. Unfortunately, the vender that was going to provide the games backed out at the last minute. The student was faced with having to take a grade of "incomplete" in the course or possibly come up with a new business idea. Ultimately, the student drove three hours to attend an auction and returned to campus with two arcade games in his van. The student now lives out of town but stops by the dormitory periodically to collect his profits.

\section{CONCLUSION}

Similar to the launch of a new business, a new course introduction can be filled with anxiety and ambiguity. When the element of risk, using real money, real business and ambiguity are added, the course may seem daunting. The result is that the course must provide a greater amount of structure than traditional courses. There is a large amount of uncertainty inherent in an entrepreneurship course and it's the instructor's responsibility to provide the guidance and reassurance during difficult times. If done properly, the experience in entrepreneurship can be successful and fulfilling for students.

\section{REFERENCES}

1. Irene M. Duhaime and Michael A. Hitt. The State of Doctoral Education in Entrepreneurship. 20th Annual Babson Entrepreneurship Research Conference, Boston June 2000. At the request of consortia organizers, this paper was also distributed to and discussed by the Entrepreneurship Division's Doctoral Consortium and New Faculty Consortium, Academy of Management meetings, Toronto, August 2000.

2. Winslow, E.K., Solomon, G.T., \& Tarabishy, A. (1999). Empirical investigation into entrepreneurship education in the United States: some results of the 1997 national survey of entrepreneurial education. Paper presented at the USASBE/SBIDA Annual National Conference. 
NOTES 